\title{
The Role of Consumer Expenses in Ensuring Forward Dynamics of The Russian Economy
}

Bagautdinova N.G. ${ }^{a}$

\author{
Safiullin L.N. ${ }^{b}$
}

Badrtdinov N.N.c1

a bc Kazan Federal University, Kazan, 420008, Russia

${ }^{1}$ Email address: verkbund@gmail.com

\section{Doi:10.5901/mjss.2014.v5n12p43}

\begin{abstract}
The article deals with the integrated approach to the contents and structure of consumer expenses, regularities of their transformation to effective demand which formation acts as necessary condition of sustainable development of modern Russian economy at post-industrial stage. The maintenance of system of state regulation of consumer expenses which includes hierarchical structuring target priorities, replacement of hold down demand actions by the measures directed on increase in expenses with high multiplier effect, carrying out moderate protectionist policy, reorientation of financial sector to integration with real sector is defined.
\end{abstract}

Keywords: Consumer expenses, cumulative expenses, effective demand, economic growth, Russian economy.

\section{Introduction}

Structural transformation of the Russian society as purpose of implementation of which acts formation of the social state providing socially focused parameters of activity of the population, assumes increase of level and quality of life, qualification and educational potential of population, improvement of working conditions and health protection. However ambiguity and discrepancy of results of structural reforms caused essential deterioration of the social indicators reflecting emergence of cyclic unemployment, inaccessibility of qualitative medical care and worthy education to considerable part of the population, elimination of many existing earlier social guarantees, falling of real income of population, strengthening in income inequality. High-quality transformations in economy found reflection in contents and structure of the consumer expenses making in modern Russia 48-50\% of gross domestic product, whereas their share in gross domestic product of the USA - more than $70 \%$ that is caused by contents and purposes of system of state regulation of economy, a condition of market infrastructure and institutional environment $[1,6,14]$.

Low activity of consumer demand remains one of the significant reasons of low rates of gain of gross domestic product of Russia which in 2014 are predicted at the level of 4,2\%. The negative consumer expectations created by an unstable trend of development of the Russian economy during the crisis and post-crisis periods, incompleteness of reforms of separate sectors of the social sphere (system of provision of pensions, education), strengthening of tax burden on business in the form of increase in rates on contributions to the state off-budget funds, low productivity of federal target programs, etc. - all this makes negative impact on the volume and dynamics of consumer expenses that, in turn, interferes with increase in cumulative expenses and formation of effective demand.

In conditions of instability of market situation on the world and national markets stimulation of consumer expenses of population becomes one of the leading factors of ensuring progressive development of the Russian economy. In turn, realization of potential of consumer expenses as a component of cumulative demand assumes need of studying of features of consumer demand for post-industrial society and the factors causing its dynamics, adaptation of available models of cumulative consumption to realities of domestic economy, development of recommendations to public authorities on inclusion of the actions, submitted on increase of consumer expenses in structure of program documents. All this predetermined the choice of subject of research, its importance in theoretical and practical aspects.

The foundation to research of problems of consumption was laid in works of representatives of classical school of political economy - T.Maltus, K. Marx, J. St. Mile, N. Senior, G. B. Seius. S. Sismondi, A. Smith, D. Ricardo, etc. Shift of attention of economic science from production to consumption happened in the second half of the XIX century and is 
connected with E.Bem-Baverk, A.Marshall, K.Menger's names. The founder of macroeconomic approach to research of consumption is J. M. Keynes which conclusions received empirical check in works of J. Duesenberry, S. Kuznets, F. Modigliani, I. Fischer, M. Friedman, etc.

Need of understanding of the processes happening in the sphere of consumption in conditions of formation of postindustrial society, and also features of models of consumer behavior for modern Russia cause special attention to problems of dynamics of expenses of households and their influence on condition and prospect of economic development. All this make necessary carrying out complex analysis of contents and components of consumer expenses, and also definition of institutional bases of a considered phenomenon.

\section{Methodology}

The theoretical and methodological basis of research became works of leading domestic and foreign experts opening regularities of consumer behavior, the principles of economic policy of the state, the mechanism of formation of consumer expenses of the population and their transformation in effective demand, influence of cumulative expenses on dynamics of the main macroeconomic indicators $[2 ; 5 ; 6 ; 12]$.

According to the scheme of economic circulation of resources, products and income, consumer expenses are defined on the basis of balance of the monetary income of households. Income of households provides resource making, distributive, reproduction, regulating, investment, consolidating functions. At the same time households possess competences of property to economic resources and act as aggregated subject in the national economy, carrying out prevailing part of cumulative expenses that defines their role in formation of reproduction contour of national economy, in ensuring dynamics of macroeconomic indicators and change of structure of national wealth. The household as the consumer is presented by a group of persons who reached certain agreements for ensuring own consumption among themselves, or the household which is consisting of one person and independently providing consumption.

In the conditions of post-industrial society the prepotent role of production in reproduction contour is replaced with prepotent role of consumption which causes special value of consumer expenses for achievement of macroeconomic balance and ensuring progressive macroeconomic dynamics. However consumer expenses possess priority within internal subordination between two autonomous components of cumulative demand (consumer and investment) as tactical and strategic objective for restoration of the complete mechanism of effective demand that is caused by its features: resistance to fluctuations of macroeconomic environment; higher specific weight in volume of cumulative expenses; placement of the institutes defining its dynamics mainly in the territory of national state which creates prerequisites for effective regulation of the factors defining expenses of consumers.

In conditions of post-industrial society deepening of objective gap between growing requirements of households and their income has inconsistent consequences: on the one hand, this contradiction acts as a source of macroeconomic dynamics, on the other hand, it becomes the reason of decrease in cumulative expenses and control of rates of economic development that causes existence of social and economic effects of measures of state impact on factors of economic development.

The analysis of the factors having impact on dynamics of volume and structure of consumer expenses allowed drawing conclusion that there are straight lines (the sum of wealth, the current income and discounted future income, norm of bank percent) and indirect (a condition of the institutional environment, biological, climatic, social and economic, family, psychological, cultural, vocational and situational) factors. Thus in the long-term period decisive influence on condition of consumer expenses is made by the maintenance of distributive and redistributive mechanisms, the loudspeaker of a wage ratio and capitalization of income, naturalization of the economic relations level and a share of shadow sector in national economy. In short-term prospect decisive influence on a condition of consumer expenses make a state and features of tax system, price level (inflation), dynamics of exchange rate and interest rates, condition of financial sector and efficiency of financial instruments.

Formation of industrial society led to expansion of sources of consumer demand which included: compensation in legal and shadow sectors of economy, social transfers, the income from business (including from self-employment), from property. Indicators of structure of the income and population expenses for the 1st and 10th decile groups and coefficients of funds in 2010 and 2013 are given in Appendix 1.

In structure of expenses of inhabitants of Russia expenses on food and alcoholic beverages occupy in total more than a third of all annual expenses of households - 35\%. (fig. 1). 


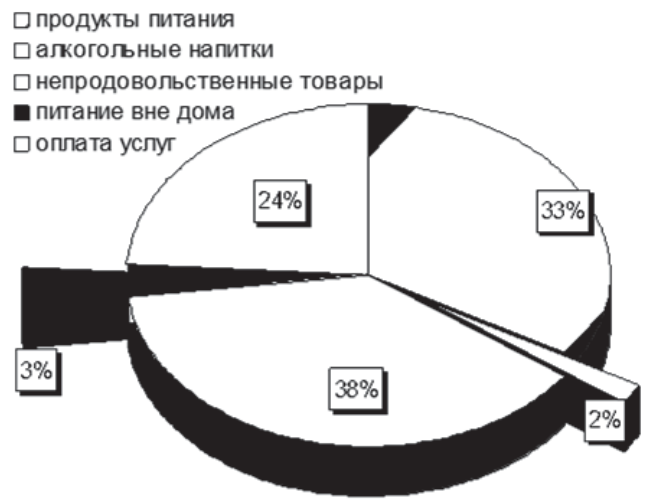

Fig. 1. Structure of expenses of inhabitants of Russia

Продукты питания Food

Алкогольные напитки Alcoholic beverages

Непродовольственные товары Nonfoods

Питание вне дома Food outdoors

Оплата услуг Fee

\section{Result}

Structural reforms in Russian economy under ignoring existing formal and informal institutional restrictions led to negative results that is defined as "an institutional trap". In the sphere of consumer expenses during research there were are revealed institutional traps connected with transformation of Pigou effect and with a priority of non-price factors in consumption function $[3 ; 7 ; 8]$.

During recession of macroeconomic indicators in process of growth of consumer price index the growth of consumer expenses is observed at decrease in the real cash remains (Pigou effect, or effect of the real cash remains). On a phase of revival of the macroeconomic environment accompanied by inflation of demand, growth of consumer expenses is observed at increase in the real cash remains that is caused by redistribution of property of the population in favor of reduction of monetary units (in any form, except for currency accumulation) for the purpose of their transformation to real estate and material benefits.

The similar choice is defined by negative consequences of falling of a macroeconomic environment (liberalization of prices, depreciation of bank deposits owing to high rates of inflation in the 90th of the XX century) for the real income of the population. Thus, the behavior of consumers is defined not by the current income and savings, but created on a previous phase of a business cycle model of similar behavior (the theory of the relative income of Duesenberry.)

Macroeconomic instability predetermined priorities of price and non price factors of consumer expenses among which the last possess a crucial role. The rate of bank percent as a price factor has no essential impact on dynamics of volumes of consumer expenses and savings owing to stereotypes which have developed in the period of reforms (institutional traps), the deposits caused by depreciation in the conditions of high inflation, low efficiency of bank management, bankruptcy of a number of banks and the credit non-bank organizations in 1998, absence of institute of bankruptcy of natural persons - borrowers. In this regard non price factors of consumer function welfare, or wealth size; level of the current income; rate of a tax on the income of natural persons, consumer expectations of change of the income and inflation; debt level; volume of transfers; condition of shadow sector of economy and efficiency of measures regulating it act as the major factors.

From 2002 to 2012 final consumption of the population becomes a leading factor of economic growth, 87\% of annual gain of real gross domestic product fall to its share on the average. (table 1 ) 
Table 1: Structure of a gain of real gross domestic product of Russia, 2002-2012.

\begin{tabular}{|c|c|}
\hline Gross domestic product component & Structure of a gain, $\%$ \\
\hline Final consumption & +91 \\
\hline including final consumption of population & +87 \\
\hline Gross accumulation & +43 \\
\hline including gross accumulation of fixed capital & +40 \\
\hline Pure export & -14 \\
\hline Statistical divergence & -20 \\
\hline Total gross domestic product & +100 \\
\hline
\end{tabular}

This tendency is favorable as the consumer demand is an important internal source of development of economy. The analysis of tendencies of consumption is carried out further by means of Keynesian functions of consumption. By the method of the smallest squares for pair linear regression we will calculate Keynesian functions of consumption for analyzed time interval. In calculations we used annual data of Rosstat on final consumption of house farms in the prices of 2003. (C, billion rubles) and the monetary income of the population ( $Y$, billion rubles) which are modified by authors to the prices of 2003 by means of consumer price indexes.

Models are constructed on intervals of 2002-2006 and 2006-2012 that corresponds to the period of growth of the Russian economy at first at the expense of other forces without consumption domination, and in the second period - with a crucial role of consumption [10; 11$]$.

$2002-2006 \mathrm{C}=1664,028+0,574 \mathrm{Y},(1)$

$2007-2012 \mathrm{C}=1190,219+0,624 \mathrm{Y} .(2)$

From the carried-out calculations it is possible to draw a conclusion that real autonomous consumption in the analyzed period decreased from 1664 billion rubles in 2002-2006 to 1190 billion rubles in 2007-2012, that is approximately for $28 \%$. In our opinion, it is explained by growth of the real located income of the population. With the increase in the real income consumers replace essentials with better and expensive substitutes. Thus the corresponding volume of consumption becomes dependent on the income, instead of autonomous as in case of decrease in income consumers will pass to goods of lower category that is consumption will react to income change. Besides, limit tendency to consumption increased in the analyzed period with 0,574 to 0,624 that is households began to spend a big share of the additional income for consumption. It led to growth of the multiplier of autonomous expenses with 2,35 to 2,66 that made economy of our country a little more sensitive to shocks of cumulative demand (autonomous expenses) and less steady.

\section{Conclusions}

Formation of an effective consumer demand is based not only on market self-regulation, but also serves as the active instrument of the state impact on macroeconomic processes. The system of state regulation of consumer expenses has to include hierarchical structuring of the target priorities defining macroeconomic policy as a whole and promoting activization of a consumer demand which presupposes replacement of demand limiting actions by the measures directed on increase in expenses with high multiplier effect, carrying out moderate protectionist policy providing protection of domestic producers, reorientation of financial sector to integration with real sector assumes.

The indirect measures of expansionist macroeconomic policy promoting expansion of internal demand in the consumer market include: decrease in tax burden, credit issue, budgetary financing of investments and priority target programs, active use of financial instruments, increase of bank interest rates for deposits, soft consumer loan. Direct methods include: continuous indexation of the income, stimulation of requirement for education and health care, the accounting of expenses on rendering educational and medical services when determining a living wage, an active antimonopoly policy in the form of control of the prices of the enterprises monopolists.

As one of limiting factors of economic growth in the conditions of deep differentiation of income is the inelastic consumer demand of a dominating basic layer, implementation of set of measures providing more uniform distribution of income is advisable, namely: increase of minimum wage to a level of living wage, overcoming of regional and branch differentiation in salary, definition of general minimum standard of welfare (no lower than 2 living wages), participation of workers in enterprise profits, obligatory social insurance, accumulative pension system, cancellation of the leveling principle when forming social payments. 


\section{References}

Anderson M., Bechhofer F., Gershuny J. (ed.). The Social and Political Economy of the Household. Oxford: Oxford University Press. 1994.

Browning M.; Bourguignon F.; Chiappori P.A.; Lechene V. Income and Outcomes: A Structural Model of Intrahousehold Allocation, The Journal of Political Economy, Vol. 102, No. 6, Dec., 1994, pp. 1067-1096.

Safiullin M.R., Elshin L.A., Shakirova A.I., Ermolaeva P.O., Prygunova M.I. (2013). Influence of Territorial Ecological Load Factors on Social and Economic Well-Being of Population: Methodology Development and Econometric Model Construction. World Applied Sciences Journal 25, 7, 1057-1061.

Fakhrutdinova, E., Karasik, E., Safina, L., Miropol'skaya, N. The role of social protection in formation of quality of work life/l World Applied Sciences Journal.Volume 27, Issue 13, 2013, Pages 72-76.

Green, W.H. Econometric analysis. New York: Macmillan Publishing Company. 2000.

Hsiao Ch. Analysis of panel data. Cambridge University Press. 1986.

Ishikawa T. Family Structures and Family Values in the Theory of Income Distribution, The Journal of Political Economy, Vol. 83, No. 5, Oct., 1975, pp. 987-1008.

Fakhrutdinova E.V., Kolesnikova J.S., Suleimanov T.D., Khalikov A.L. The interrelation of the problems of the youth labour market and the "brain drain". Life Science Journal 2014; 11(6s): 473 - 477.

Lancaster K. A New Approach to Consumer Theory // Journal of Political Economy. Apr. 1966.

Safiullin L.N., Bagautdinova N.G., Ismagilova G.N., Safiullin N.Z. The correlation of the consumer utility, product demand and grade. Middle-East Journal of Scientific Research 13 (Socio-Economic Sciences and Humanities). - 2013.

Kirshin I.A., Gareev B.R. Theory of constraints in value based cost management // World Applied Sciences Journal (Economics, Management and Finance). - 2013. - №27. - P. 102-106.

Kirshin I.A. Modeling the long-term trend of accumulation of knowledge. Life Science Journal 2014; 11(6s): 482 - 486.

Wooldridge, J. M. Econometric Analysis of Cross Section and Panel Data. Cambridge, Massachusetts: The MIT Press. 2002.

Yitzhaki S. 2002. Do we need a separate poverty measurement?// European Journal of Political Economy, Vol. 18, 61-85. 


\section{Appendix 1}

Structure of monetary income and expenses in the first and the tenth decile groups and coefficients of funds for them in 2010 and 2013. [1]

\begin{tabular}{|c|c|c|c|c|c|c|}
\hline \multirow{3}{*}{ Item of income and expenses } & \multicolumn{3}{|r|}{2010 г. } & \multicolumn{3}{|c|}{2013 г. } \\
\hline & \multicolumn{2}{|c|}{$\begin{array}{c}\text { Decile group, } \\
\%\end{array}$} & \multirow{2}{*}{$\begin{array}{c}\text { Coefficient of funds, } \\
\text { times }\end{array}$} & \multicolumn{2}{|c|}{$\begin{array}{l}\text { Decile group, } \\
\%\end{array}$} & \multirow{2}{*}{$\begin{array}{c}\text { Coefficient of funds, } \\
\text { times }\end{array}$} \\
\hline & 1 & 10 & & 1 & 10 & \\
\hline Income, in total & 100,0 & 100,0 & 15,2 & 100,0 & 100,0 & 16,8 \\
\hline Income from business activity & 16,6 & 8,8 & 8,1 & 14,6 & 7,8 & 9,0 \\
\hline labor compensation & 42,7 & 33,7 & 12,0 & 44,4 & 35,4 & 13,4 \\
\hline Income except labor compensation & 1,3 & 1,5 & 18,2 & 1,2 & 1,5 & 20,3 \\
\hline Social payments & 25,2 & 7,7 & 4,6 & 24,0 & 6,5 & 4,6 \\
\hline - pensions & 20,8 & 4,1 & 3,0 & 18,1 & 3,6 & 3,4 \\
\hline - grants and social care & 4,0 & 1,3 & 4,8 & 5,3 & 1,7 & 5,4 \\
\hline - educational grants & 0,3 & 0,0 & 0,8 & 0,6 & 0,0 & 0,9 \\
\hline - insurance compensations & 0,1 & 2,3 & 364,5 & 0,0 & 1,2 & 406,5 \\
\hline - prizes on lotteries & 0,0 & 0,0 & 25,6 & 0,0 & 0,0 & 28,5 \\
\hline Income from property & 1,7 & 16,9 & 153,8 & 1,8 & 13,9 & 127,9 \\
\hline - dividends & 0,3 & 5,3 & 292,4 & 0,3 & 6,2 & 326,1 \\
\hline - percent on deposits & 0,4 & 1,2 & 50,1 & 0,4 & 1,4 & 55,9 \\
\hline - income on the Central Bank & 0,3 & 8,2 & 437,6 & 0,1 & 1,9 & 488,0 \\
\hline - preliminary compensation on deposits & 0,6 & 0,0 & 1,1 & 0,8 & 0,1 & 1,3 \\
\hline - income from real estate sale & 0,1 & 2,1 & 293,4 & 0,2 & 4,3 & 327,2 \\
\hline Income from currency sale & 0,9 & 7,0 & 125,1 & 0,9 & 7,4 & 139,5 \\
\hline Other income & 11,7 & 24,4 & 31,7 & 13,1 & 27,5 & 35,4 \\
\hline Expenses, in total & 99,7 & 97,8 & 14,9 & 99,1 & 94,3 & 16,0 \\
\hline Goods & 67,3 & 42,3 & 9,6 & 71,0 & 41,5 & 9,8 \\
\hline Services & 22,0 & 14,9 & 10,3 & 22,1 & 14,2 & 10,8 \\
\hline Obligatory payments and contributions & 4,4 & 10,5 & 36,6 & 5,2 & 11,8 & 38,3 \\
\hline Savings in deposits and in Central Bank & 0,4 & 9,4 & 355,3 & 0,5 & 12,1 & 386,1 \\
\hline Expenses on real estate purchase & 0,5 & 3,6 & 102,7 & 0,9 & 5,8 & 109,4 \\
\hline Expenses on foreign currency purchase & 0,9 & 15,4 & 268,3 & 0,5 & 9,2 & 290,4 \\
\hline $\begin{array}{l}\text { Change of means on non corporate sole proprietor } \\
\text { accounts }\end{array}$ & 9,2 & 5,4 & 8,8 & 6,5 & 3,5 & 9,1 \\
\hline Change of debt on the credits & $-1,6$ & $-5,2$ & 50,1 & $-2,1$ & $-7,1$ & 56,2 \\
\hline The money sent on transfers & $-3,5$ & 1,4 & $-6,1$ & $-5,6$ & 3,2 & $-9,7$ \\
\hline Excess of income over expenses & 0,3 & 2,2 & 100,8 & 0,9 & 5,7 & 107,5 \\
\hline
\end{tabular}

